\title{
Editorial
}

\section{Três boas notícias}

Após um ano de trabalho, consolidamos um corpo editorial de pesquisadores renomados e passamos a receber artigos de melhor qualidade. Neste número temos duas novidades para divulgar aos nossos leitores. A primeira é que o Conselho Editorial decidiu formar um núcleo de assessoramento com pessoas que tiveram destaque na condução política da Associação Brasileira de Psiquiatria, e que oferecem suporte logístico ao processo de mudança engendrado pelos editores.

Esse novo núcleo editorial passa a se chamar Conselho Consultivo e terá a função de captar as reações dos profissionais de saúde que compõem a audiência da revista, assim como a de sugerir temas e assuntos que poderiam ser explorados pelo corpo editorial. Eles também serão fundamentais para levar os ideais e a missão científica da revista para editores em futuras mudanças, garantindo continuidade nos processos sucessórios.

A segunda novidade é que a revista passa a ter um serviço de secretaria exclusivo, conseqüência do aumento da demanda de artigos nos últimos anos. Desenvolvemos um novo fluxo de avaliação de artigos, nos quais esperamos dar uma resposta mais ágil na decisão de aceitação ou rejeição dos artigos submetidos. Estamos com nossa agenda praticamente atualizada e esperamos que nossos leitores e colaboradores possam se beneficiar das novas medidas.

Outra novidade importante é a versão da RBP na SciELO (Scientific Electronic Library Online, www.scielo.br), que já está em operação, podendo a revista ser consultada em inglês, português e espanhol - com texto integral.

Boa leitura e boa navegação!

Jair de Jesus Mari

Editor 